\title{
Earnings Differentials between the Public and Private Sectors in China: Exploring Changes for Urban Local Residents in the 2000s*
}

\author{
Sylvie Démurger \\ Université de Lyon, Lyon, F-69003, France \\ CNRS, GATE Lyon St Etienne, 93 Chemin des Mouilles, Ecully, F-69130, France \\ E-mail: demurger@gate.cnrs.fr
}

\section{Shi Li}

School of Economics and Business Administration Beijing Normal University, 19, Xinjiekouwai Dajie, Beijing 100875, China Email: lishi@bnu.edu.cn

\author{
Juan Yang \\ School of Economics and Business Administration \\ Beijing Normal University, 19, Xinjiekouwai Dajie, Beijing 100875, China \\ E-mail: yangjuan@bnu.edu.cn
}

Corresponding author: Juan Yang (yangjuan@ bnu.edu.cn).

\footnotetext{
* We are grateful to the editor and the two anonymous referees for their thoughtful comments on an earlier version of the paper.
} 


\title{
Earnings Differentials between the Public and Private Sectors in China: Exploring Changes for Urban Local Residents in the 2000s
}

\begin{abstract}
:
This paper analyzes the changes in public-private sector earnings differentials for local residents in urban China between 2002 and 2007. We find that earnings gaps across ownership sectors decreased during this period and that the convergence trend has been in favor of the private and semi-public sectors as opposed to the public sector. This trend is in sharp contrast to what occurred at the turn of the $21^{\text {st }}$ century when employees the government and state-owned enterprises were found to enjoy a privileged situation. Differences in endowments are found to play a growing role in explaining earnings differentials. However, although it is becoming less of an issue, segmentation across ownership remains important, especially for high-wage earners.
\end{abstract}

Keywords: labor market, earnings differentials, segmentation, enterprise ownership, China.

JEL classification: J31, J42, P23, O53. 


\section{Introduction}

Three decades of economic reform have brought tremendous changes to every sector of China's economy. The labor market is no exception, and it has been particularly affected by important policy and institutional changes at the turn of the $21^{\text {st }}$ century. State sector reform accelerated after the Chinese Communist Party's 15th Congress held in September 1997, which encouraged both the corporatization of large state-owned enterprises (SOEs) and the restructuring of small SOEs. However, the same Congress recognized private enterprises as an important component of the economy and stressed the rule of law. As a direct consequence, the urban labor market has been reshaped through the unprecedented growth of unemployment and the reallocation of labor from the public to the private sector. In the meantime, competition among workers in the urban labor market has sharply increased due to a massive exodus of the rural labor force that saw an estimated 140 million rural workers move to cities by 2008 (National Bureau of Statistics of China, 2010).

In the context of a transitional economy, these dramatic changes raise a number of issues regarding the direction in which the urban labor market is moving. A key aspect to be explored is whether labor is participating in a true market and whether enterprises of different ownership types operate in a competitive fashion. Academic research conducted on data collected in the 1990s and early 2000s highlighted the incompleteness of reform as well as the remaining rigidities in a labor market composed of several segments with distinct rules for wage determination and limited mobility among segments (e.g., Chen et al., 2005; Démurger et al,. 2007a; Dong \& Bowles, 2002; Knight \& Song, 2003; Li \& Bai, 2005).

Moreover, with the growth of China's economy and rising average urban wages, earnings gaps have triggered a vigorous debate in China. Among recent studies that document the world's fastest recent growth in labor earnings, Ge and Yang (2010) indicate that the earning gains in China between 1992 and 2007 is the result of a conjunction of growth in basic wages and in wage premiums not only related to skills, but also with regard to enterprise ownership. In particular, they find much higher gains in wage premiums for state employees than for non-state employees. In the Chinese context, enterprise ownership is an important question because it is linked with the issue of whether the 
government can provide an equal and efficient business environment for all types of companies to develop and maximize social welfare. Given that the number of enterprises in the public sector decreased from about $99 \%$ of total companies in 1978 to merely $10 \%$ in 2007, it is also interesting to investigate whether the remaining companies in the public sector still enjoy a privileged position in the labor market because of particular government policies.

There is a vast body of literature on public-private wage differentials in both developed and developing countries. ${ }^{1}$ Research on developed countries has shown that the public sector pays more on average than the private sector, not only because public employees have better qualifications but also because they enjoy higher returns for their productivity. Empirical investigations of European transitional economies have highlighted different patterns with a wage premium in favor of the private sector after economic liberalization (Adamchick \& Bedi, 2000; Leping, 2006; Lokshin \& Jovanovic, 2003). This wage gap is especially large for educated employees; this condition has been interpreted as adding further difficulties in attempts by the state sector to retain skilled workers. With regard to China, evidence from the mid-nineties shows that workers in the public sector had little incentive to move to a different sector. The major reason for this immobility was that the higher-than-market-clearing-level earnings premium provided to workers in state-owned units (Chen et al., 2005; Zhao, 2002). Furthermore, segmentation across ownership sectors continued to increase until the end of the 1990s with the gap between the privileged segments of the labor market and the most competitive segments widening over time (Démurger et al., 2007a).

The release of new data from the Project on Rural-Urban Migration in China (RUMIC-2007) in 2008 makes it possible to analyze whether China's labor market is still segmented by ownership sector in terms of earnings differentials. The comprehensive information on personal characteristics provided by available micro datasets (RUMIC-2007 and CHIP-2002) enables us to investigate wage compensation by controlling for individuals' most important characteristics. Previous research on China's labor market segmentation utilized data for the year 2002 or before. However, during the period between 2002 and 2007, China's economic growth averaged 10.8\% in real terms, and China became increasingly integrated into global markets, especially after joining the World Trade

\footnotetext{
${ }^{1}$ See Gregory \& Borland (1999) for a comprehensive review of the early papers.
} 
Organization in 2001. In addition, private companies have been allowed to enter state-controlled areas, such as steel, aluminum and automobiles, in recent years. Private high-tech enterprises, especially internet companies, are soaring with many breaking into the top 500 companies in China. This development implies that the old-style companies, such as state-owned enterprises and urban collective companies, must compete more intensely with market-oriented companies, including private companies, joint-venture companies, or foreign companies.

In the context of the intensified economic reform that occurred between 2002 and 2007, we propose to investigate the trend and the determinants of the earnings gap across ownership during this period. We first analyze average gaps by using the Oaxaca-Blinder decomposition technique and subsequently account for different patterns in different percentiles for different ownership sectors by applying the Juhn-Murphy-Pierce decomposition method.

The remainder of the paper is organized as follows. Section 2 describes the development of various types of enterprises in China. Section 3 introduces the dataset along with some descriptive statistics. Section 4 discusses econometric results on earnings equations by enterprise ownership. Section 5 and Section 6 present decomposition results of earnings gaps across ownership sectors during the period ranging from 2002-07. Section 7 contains the conclusion.

\section{Economic reforms and the evolution of ownership}

After China became a socialist country in 1949 , most of the means of production belonged to the state, and private and individual economic activities were made illegal. Therefore, within the period of the first five-year plan, the percentage of public ownership increased from $21.3 \%$ in 1952 to $92.9 \%$ in 1956. When economic reforms were initiated in 1978 , the national economy was dominated by publicly owned companies, which consisted of state-owned companies and collective enterprises. State-owned companies and collective enterprises accounted for $24 \%$ and $76 \%$, respectively, of the total number of industrial companies and $78 \%$ and $22 \%$, respectively, of total industrial production.

One major aspect of China's economic reform was to encourage the development of the non-state sector in the economy. Through revising a series of laws and regulations, the government gradually 
allowed private and foreign companies to co-exist with state-owned and collective companies. In 1988, the State Council issued the "Tentative Stipulations on Private Enterprises" to govern the registration and management of private firms, and, in 1993, the Company Law provided the legal framework for the development of limited liability companies and shareholding companies (Démurger et al., 2007a). Hence, various forms of non-public ownership, such as private-owned, foreign-invested, joint-venture, share-holding and stock companies, as well as self-employment, became alternatives to state-owned companies. More recently, efforts have been made to ensure fairer competition between the public and the private sectors and to open more industries to the private sector. In 2003, new regulations allowed non-state enterprises to enter the steel and aluminum industries and even parts of the national defense industries. In February 2005, the State Council issued "36 Suggestions to Encourage and Support Non-State-Owned Economic Development" in order to reduce barriers to market entry and to stimulate private investment.

The development of the non-state sector helped promote competition among all of the companies as well as allocate resources more efficiently. Before the reform, because resources were allocated according to a national plan and the economy was dominated by public ownership, there was no competition among enterprises or employees. Allowing private and foreign companies to enter the labor market made it possible to improve the national economy as a whole and to promote prosperity. The other advantage was the alleviation of employment pressure. With the baby boom and soldiers transferring to non-military sectors, the labor force increased by more than 10 million every year, and the non-state sector became a major channel for absorbing this growing labor force.

Hence, whereas employment in the public sector had continued to rise continuously until the mid-1990s, it began to decrease in 1995 with a huge deceleration in $1998(-18 \%)$, which was the pivotal year in SOE reforms. Since that year, the number of workers in both SOEs and urban collective enterprises (UCEs) has continued to decrease, from 144.6 million in 1995 to 71.4 million in 2007 (National Bureau of Statistics 2008) for a total decrease of 50\%. The public sector share in urban employment dropped from $76 \%$ to $24 \%$ over the same period. In contrast to the downsizing of the public sector, the private sector share in urban employment has increased from $16 \%$ in 1995 to $42 \%$ in 2007. The dramatic increase of the private-sector share in urban employment can be attributed to the 
development of both private or individual enterprises and foreign-invested enterprises as well as to the emergence of new forms of ownership from the mid-1990s onward, including limited liability corporations and share-holding corporations. From 1995 to 2007, employment in foreign-invested enterprises tripled (from 5.1 million to 25.8 million), and employment in private and individual enterprises almost quadrupled (from 20.4 million to 78.9 million). Moreover, the number of people employed in new ownership forms multiplied by approximately ten from 3.2 million in 1995 to 30.8 million in 2007. All of these figures clearly indicate a significant shift in the employment structure at the turn of this century. China experienced a situation similar to what Eastern European countries experienced during the process of moving the labor force from the public to the private sector.

Urban wage-setting mechanisms have also fundamentally evolved over the period of these reforms. ${ }^{2}$ By giving more autonomy to SOEs to determine wages and bonuses, the 1994 wage reform led to a gradual shift from state-sector wage grids based on seniority to more flexible wage settings. As highlighted by Knight and Li (2005), wages became more strongly linked to the profitability of the enterprise in the 1990s, which contributed to a widening of wage inequality between employees of loss-making firms and those of profit-making firms. The restructuring of SOEs from 1997 onward further impacted the wage structure by redistributing the working population into the private sector where wages are linked to individual productivity. Moreover, as documented by Xing (2010), compensation in the state-owned sector became more sensitive to work performance at the beginning of the 2000s as part of an effort to move closer to market mechanisms in the determination of wages.

\section{Data and descriptive analysis}

\subsection{Summary statistics by ownership}

The data used in this paper come from two sources: the Chinese Household Income Project, which was conducted in 2003 for the year 2002 (hereafter termed CHIP-2002) and the Project on Rural-Urban Migration in China (hereafter designated RUMIC-2007) carried out in 2008 for the year 2007. For both surveys, the questionnaire was designed by Chinese and foreign researchers and

\footnotetext{
${ }^{2}$ Early reforms of the urban wage-setting system are documented in Meng (2000).
} 
implemented by China's National Bureau of Statistics (NBS). ${ }^{3}$ The CHIP-2002 urban survey was collected from 6,835 households in 12 provinces inhabited by a total of 20,632 residents. The RUMIC-2007 urban survey was collected from 5,003 households in nine provinces with a total of 14,699 residents. The two datasets cover urban residents only, that is, people living in cities who hold an urban household registration (hukou). Consequently, unregistered urban workers, such as rural migrants, are not included in the analysis. Because rural migrants represent a much larger portion of the urban labor force during the period under study, omitting this particular group may leave out valuable insights into the evolving labor market in the 2000s. This omission is a clear limitation of our analysis in terms of drawing inferences for the entire labor market in urban China. However, it is still possible to discuss the potential bias by comparing the excluded group with its closer counterpart. It is widely recognized that rural migrant workers compete with urban unskilled workers in the urban labor market (Appleton et al., 2005; Ge \& Yang, 2010). Hence, excluding rural migrants from the analysis may impact the findings at the lower end of the earnings distribution spectrum. This characteristic of the data calls for a cautious interpretation of the results at the lower percentiles.

For the sake of comparison between the two surveys, we keep only the jointly surveyed seven provinces' observations in our sample. The seven examined provinces are Jiangsu, Anhui, Henan, Hubei, Guangdong, Chongqing and Sichuan ${ }^{4}$. In addition, we further restrict the sample to individuals aged between 16 and 60 in full-time employment and earning positive wages. ${ }^{5}$ The final sample size amounts to 5,446 workers for 2002 and to 5,051 workers for 2007 .

Enterprise ownership as analyzed in this paper is divided into five categories (see Table 1):

\footnotetext{
3 Although the sampling design for both surveys is based on that of the annual urban household survey conducted by the NBS, there is one discrepancy between the two datasets that is worth mentioning here. Indeed, the RUMIC-2007 data were collected from the NBS new sample. The sampled households who entered the survey in 2008 self- reported their income from memory, unlike households in the 2002 survey, who based their responses on recorded income. According to NBS, remembered income might be less accurate than recorded income. It is, unfortunately, not possible to provide robustness checks on this issue, but we believe that given the scope of the identified effects in our analysis, the bias, if any, should not be strong.

${ }^{4}$ Restricting the analysis to individuals from the jointly surveyed provinces may raise concerns regarding representativeness of the sample. To check the robustness of our results, we have run the analysis for the year 2002 on all the provinces included in the 2002 survey. Results are consistent with the estimations provided on the seven provinces alone, which lends support to the notion that our sample is relatively well representative. 5 After restricting the sample to full-time employment, the minimum age of the sample increased to 18 . One may argue that with the expansion of higher education, most individuals aged 18-22 are still at school and this characteristic could result in sample selection bias. However in RUMIC-2007, the percentage of individuals aged 18-22 who are still at school account for only 3.6\% of this age group, and the percentage is even lower in 2002. Hence, such a bias, if any, should have little effect our estimation results.
} 
state-owned enterprises (SOEs), government agencies or institutions (GAIs), urban collective enterprises (UCEs), private or individual enterprises (PIEs), and foreign-invested enterprises (FIEs). In each survey, respondents were required to record the ownership of their company. In CHIP-2002, the ownership was separated into 13 types, and, in 2007, it was separated into 16 types. In order to simplify the analysis, we consider five categories that are consistent over time. ${ }^{6}$ In this classification, the SOEs category includes any enterprise with a dominant state share regardless of who owns the other shares (including foreigners or Chinese private investors). The "FIEs" category is more restrictive because it contains only solely foreign-invested companies and foreign-owned joint-venture companies. This classification choice may explain why, despite the fact that foreign direct investment increased substantially from 2002 to 2007, the share of FIEs in our analysis does not change significantly over time (see Table 2).

Descriptive statistics on individual characteristics by ownership sector are shown in Table 2. The gender distribution does not change significantly across a number of years with males representing $56-57 \%$ of urban workers and being particularly concentrated in SOEs where they account for respectively $59.5 \%$ and $61.4 \%$ of the totals in 2002 and 2007 . To some extent, this distribution suggests that males may enjoy some advantages in recruitment and income in the public sector as compared with females. However, a noteworthy change occurred between 2002 and 2007 for UCEs where females were traditionally overrepresented (Démurger et al., 2007b; Maurer-Fazio et al., 1999). In 2007 , males account for $53.7 \%$ of workers in UCEs, as opposed to only $43.9 \%$ in 2002 . While it remains the lowest share of males across ownership, the difference is no longer significant in comparison with other categories (aside from SOEs). As further documented below, this change reflects an improving situation for UCEs where increased competition may have boosted productivity and attracted more workers.

The comparison between 2002 and 2007 shows a slight decrease in the average age of the workforce. This decrease is more marked in UCEs and in the private sector than in the public sector (SOEs and GAIs). In both years, the public sector, on average, employs older workers than does the

\footnotetext{
${ }^{6}$ Our classification is also consistent with that of Démurger et al. (2007a), which enables us not only to analyze changes in the 2000s but also to compare our results with what occurred in the mid-1990s.
} 
private sector. As expected with the expansion of higher education after 1999, the average educational attainment of the workforce measured in years of schooling has substantially increased over time, by almost one year in the 5-year period (from 11.34 years to 12.21 years). Whereas, in 2002, the average education level of workers was above 12 years of schooling only in GAIs, each ownership category has benefited from the increase in the education level such that the absolute gap in educational attainment of workers across ownership decreased from 2.54 years to 2.1 years in 2007. This evolution demonstrates that aside from public entities, FIEs are more and more able to attract talented youngsters in 2007.

The average amount of experience in the current job (expressed in years) is much shorter in 2007 for all of the sectors except GAIs than in 2002. The sharpest decrease occurred for the semi-public sector (UCEs) and, to a lesser extent, for the private sector (both PIEs and FIEs). This evolution probably signals increased job mobility in these sectors, while jobs in the public sector (SOEs and GAIs) are still the most stable, and individuals would not easily leave their positions there.

\subsection{The evolution of earnings and their distribution by ownership}

Table 3 reports summary statistics regarding earnings as classified by ownership sector. Total annual earnings are composed of reported wages, bonuses, in-kind earnings, subsidies and pension income. Hourly earnings are calculated by dividing total annual earnings by the number of declared hours worked in a year. In addition, earnings are adjusted for provincial purchasing power differences by using an updated set of Brandt and Holz (2006) urban provincial-level spatial price deflators in order to account for differences in living standards across cities.

In the five-year period from 2002 to 2007, earnings differentials between enterprises of different ownership sectors have changed markedly. Real earnings have almost doubled on average but at a different pace across enterprises. The state sector experienced the slowest growth in annual and hourly earnings ( $88-92 \%$ for SOEs, and $62-63 \%$ for GAIs), and, on the contrary, both UCEs and the private sector experienced earnings increase of more than $110 \%$ (up to a maximum $138 \%$ for hourly earnings in UCEs). As compared to what occurred between 1995 and 2002 (Démurger et al., 2007a), differentials across enterprises have somehow re-adjusted toward more equality thanks to the dramatic 
increase of earnings in both UCEs and PIEs. While total earnings are the highest in GAIs in 2002, the much slower earnings increase in GAIs between 2002 and 2007 moved them down to the second rank after FIEs. ${ }^{7}$ However, UCEs as well as PIEs have seen their relative position dramatically improve (again as opposed to what occurred between 1995 and 2002), the gap in average total earnings shrinking from 0.7 to 0.87 for UCEs and from 0.81 to 0.94 for PIEs. Last, SOEs stand in the middle, and the almost doubling of earnings in this part of the state sector allowed workers to maintain their intermediate position with a gap to average earnings very close to one observed for two years. ${ }^{8}$

Another interesting point concerns the ongoing convergence of working hours between the public and the private sectors. For the period from 1995 to 2002, the number of hours worked per week continued to decrease in both PIEs and FIEs. However, the working hours slightly increased in the public sector, although they remained shorter than in the private sector in 2007. One possible reason for this convergence is that competition in SOE and GAI sectors has increased, and employees may have to work harder to maintain their position. Simultaneously, PIEs and FIEs began to pay greater attention to employees' rights.

Gini coefficients highlight a general trend of increasing inequality in annual and hourly earnings. For the entire sample, the Gini coefficient for hourly earnings increased from 0.377 to 0.406 between 2002 and 2007. Although PIEs continuously exhibit the largest earnings dispersion over time, ${ }^{9}$ the increase in earnings inequality has been more pronounced in the public sector (including UCEs), thereby resulting in a convergence of earnings distributions across sectors between 2002 and 2007.

Non-parametric kernel density estimations for the distribution of the logarithm of hourly earnings by ownership category and by year are presented in Figure 1. For each year, the graph displays the distribution for the entire sample as well as for ownership category subsamples.

The upper panel of Figure 1 displays kernel density estimates for the year 2002. Hourly earnings

\footnotetext{
${ }^{7}$ Interestingly, this movement is a complete reversal compared to the situation in the period from 1995 to 2002 (see Démurger et al., 2007a).

${ }^{8}$ One should note, however, that reported earnings may not fully reflect actual individuals' income in the state sector, which may result in an underestimation of earnings. Indeed, the welfare system in SOEs and GAIs is still much better than in FIEs and PIEs, but it is difficult to collect all of the information on this type of compensation, especially regarding non-pecuniary welfare. Given the comparatively high wages in these two sectors, plus non-observable income, jobs in SOEs and GAIs can still be as attractive as, or even more attractive than, jobs in FIEs.

9 This trend confirms the more unequal distribution of hourly wages in the private sector compared to the public sector that was observed in the 1990s (see Chen et al., 2005; Xing, 2008).
} 
in GAIs are, on average, higher than in other sectors. This characteristic can be seen in both the position of the curve mostly to the right and a higher level of kurtosis. In addition, the spread is narrow and highly concentrated around the mean. FIEs are ranked second with average earnings only slightly higher than in SOEs but with a larger width that illustrates a wider distribution. The hourly wages in PIEs are the lowest among the five sectors with a distribution skewed to the right, which indicates that some earnings in PIEs are fairly low.

As illustrated in the bottom panel of Figure 1, patterns have not changed much over time except that the five lines appear closer in 2007 when compared to 2002. This finding further illustrates the converging trend of the hourly earnings gap among the five sectors. In 2007, FIEs exhibited characteristics of hourly wage distributions that were more desirable than GAIs. Together with higher average hourly earnings, FIEs also exhibit a flat tail in the left part of the distribution, indicating that there are not many low-wage earners in this sector. ${ }^{10}$ Moreover, the distributions for GAIs and UCEs are fairly close except that the hourly wages distribution of GAIs is on the right of that of UCEs. Finally, the kurtosis is the highest in SOEs, suggesting a sharper peak and fatter tails of hourly earnings distribution in the state sector.

\section{The determinants of hourly earnings}

Tables 4 and 5 present OLS estimations of an augmented Mincerian hourly earnings function (Mincer, 1974) run separately by enterprise ownership and by year. ${ }^{11}$ The Mincerian earnings equation takes the following form:

$$
w_{i r}=\beta_{i r} X_{i r}+u_{i r}
$$

where subscript $r \in[1,5]$ represents the five different ownership categories defined above; $w_{i r}$ is the natural logarithm of hourly earnings (adjusted for provincial purchasing power differences) for individual $i$ in enterprise $r ; X_{i r}$ is a vector of her individual socio-demographic characteristics and $\beta$

\footnotetext{
${ }^{10}$ This may reflect our ownership classification. Indeed, FIEs only include foreign-owned enterprises and foreign-controlled enterprises, which are mainly concentrated in higher-end industries.

${ }^{11}$ Card (1999) provides a brief introduction of all kinds of estimating methods and their respective advantages and disadvantages on the return to education. He argues that the OLS estimating method is still the most robust technique.
} 
provides the set of returns for each observed characteristic. $X$ includes gender, education (measured in years of schooling as reported in the surveys), work experience ${ }^{12}$ and its square, work experience in the current occupation, on-the-job training (dummy variable) and regional dummies for coastal provinces and for capital cities. ${ }^{13}$ The residual $u_{i r}$ stands for all the unobservable factors that may affect individual hourly earnings $w$.

Returns to education are significant in all sectors for both years and are the highest in FIEs. A comparison over time also reveals interesting changes: ${ }^{14}$ while returns to education remain stable in UCEs, FIEs and GAIs between 2002 and 2007, they exhibit a significantly decreasing trend in both SOEs and PIEs, which resulted in a growing gap across sectors. Therefore, the range of returns on education, depending on enterprise ownership, moved from 5.53\%- $9.10 \%$ in 2002 to $3.83 \%-9.07 \%$ in 2007.

Linear and quadratic terms in experience are significant in the public sector (SOEs and GAIs) as well as in the private sector (PIEs) but are non-significant in both UCEs and FIEs for both 2002 and 2007. As discussed in Chen et al. (2005), the observed difference in experience earnings profiles between the public sector and other sectors suggests that in SOEs and GAIs, seniority remains an important component in the determination of wages. Interestingly, experience is also important in the private sector. A comparison between 2002 and 2007 shows much earlier earnings peaks for the year 2007, which suggests that older people have seen their relative position deteriorating over time. Indeed, whatever the enterprise, the experience profile begins decreasing after 15 to 20 years of experience, while it began decreasing after 30 years of experience in 2002. However, non-significant returns to experience in FIEs can be related to the fact that workers in these enterprises are younger and have

\footnotetext{
${ }^{12}$ Because the actual work experience is not reported in the 2007 survey, we use potential work experience, defined as age minus years in school minus six, for both years. Nevertheless, earnings regressions using actual work experience for the year 2002 indicate that there is no obvious bias in using potential work experience instead of actual work experience.

${ }^{13}$ It is widely recognized that excluding relevant exogenous variables from the wage regression may bias upward the unexplained part in the subsequent decomposition. However, some of these explanatory variables, including industry and occupation, are clearly choice variables and are, therefore, endogenous with no variable in our dataset to credibly instrument those endogenous variables. In the absence of reliable instruments, we had to make a statistical compromise between endogeneity and omitted variables. We chose to limit the potential for endogeneity bias by using a sparse set of right-hand side variables in the earnings equation. The potential omitted variable bias should then be kept in mind during the interpretation of the results.

${ }^{14}$ Although coefficients are not directly comparable across years, the significance of the difference has been checked by pooling the data and adding interaction terms for all variables with a "2007" dummy.
} 
less experience than in other types of enterprises (see Table 2).$^{15}$ The introduction of another indicator of experience that measures the number of years in the company adds some interesting results for foreign-invested firms. Indeed, the associated coefficient for FIEs, which is significantly higher in 2007 than in 2002, indicates that the experience that counts for FIEs is experience that accumulated in the enterprise rather than overall experience (which may have been accumulated in the less efficient public or semi-public sectors).

Returns to gender also exhibit noteworthy differences across ownership and over time. In 2002, being a male in PIEs increased log hourly wages by about $21.5 \%$, while the increase was only $8 \%$ in GAIs. The "male premium" increased dramatically (and significantly) over time in GAIs where it reached a level of $18.3 \%$. This result partly reflects the findings by Song and Li (2010) that gender wage inequality increased during the period 2002-07. Interestingly, FIEs do not appear to favor males more than females because the coefficient for the gender dummy is never significant.

Finally, location variables show a premium of both living in the coast and living in a capital city for all enterprises except FIEs in both years. Because coastal provinces are characterized by a higher level of industrialization and urbanization, the coastal premium may reflect certain advantages stemming from agglomeration economies. Interestingly, the comparison of coefficients over time indicates a significantly increasing coastal premium for SOEs, which have caught up with other enterprise ownership types in the level of the premium. This finding might indicate increased competition between SOEs and the non-state sector in coastal areas.

\section{Oaxaca-Blinder decompositions}

In order to analyze earnings differentials between individuals belonging to different enterprises, we first use the Oaxaca-Blinder method (Blinder, 1973; Oaxaca, 1973) to decompose mean

\footnotetext{
${ }^{15}$ Interestingly, the absence of a significant wage premium for job experience in the foreign sector is persistent over time (see Chen et al., 2005). As for UCEs, the non-significant relationship between experience and wage levels seems more unusual. One explanation might be related to the relatively small sample size of UCEs for both years. Additionally, one may argue in line with Appleton et al., (2005) that insignificant returns to experience in the urban collective sector are consistent with a move toward a more competitive labor market in which seniority is no longer overvalued.
} 
differences in log earnings into two components: one that is attributable to the differences in mean endowments of workers across ownership and one that is attributable to differences in returns to these endowments.

The observed average log-earnings difference between two enterprises of different ownership, $r_{1}$ and $r_{2}$, can be defined as:

$$
\Delta \bar{w}_{r_{1} r_{2}}=\bar{w}_{r_{1}}-\bar{w}_{r_{2}}
$$

where bars indicate mean values. Substituting equation (1) into (2) yields:

$$
\Delta \bar{w}_{r_{1} r_{2}}=\bar{X}_{r_{1}}^{\prime} \hat{\beta}_{r_{1}}-\bar{X}_{r_{2}}^{\prime} \hat{\beta}_{r_{2}}
$$

where hats denote estimated coefficients from separate earnings equations.

Assuming that a non-discriminatory wage structure $\beta^{*}$ is known, the log-wage differential can be decomposed in the following way:

$$
\Delta \bar{w}_{r_{1} r_{2}}=\left(\bar{X}_{r_{1}}-\bar{X}_{r_{2}}\right)^{\prime} \beta^{*}+\left[\bar{X}_{r_{1}}^{\prime}\left(\hat{\beta}_{r_{1}}-\beta^{*}\right)-\bar{X}_{r_{2}}^{\prime}\left(\hat{\beta}_{r_{2}}-\beta^{*}\right)\right]
$$

Equation (4) shows that the earnings gap between ownership $r_{1}$ and ownership $r_{2}$ can be decomposed into two parts. The first term can be interpreted as the part of the log-earnings differential, due to differences in average individual characteristics between different ownerships. It measures how much individuals in ownership $r_{l}$ would earn if they had the same characteristics as those in ownership $r_{2}$. The second (bracketed) term represents the amount by which earnings between two different ownership sectors differ from the assumed non-discriminatory wage structure. This term is the "unexplained" or residual component of the earnings gap. This effect can be interpreted as the part due either to segmentation or to different productivity levels. In other words, the fact that individuals with the same characteristics are paid differently in different ownership sectors might be due to different production processes that result in different individual productivity levels across ownership sectors or to particular institutional factors, such as monopolistic power, that lead to the return gap.

Several approaches to estimating the non-discriminatory wage structure $\beta^{*}$ have been adopted in the literature. Following Oaxaca's (1973) seminal paper, one may assume that discrimination is directed toward one group only and take the other group's wage structure as the non-discriminatory structure. However, this assumption leads to the well-known "index number problem," resulting in 
various weighting schemes being put forward in the empirical literature (Neumark, 2008; Jann, 2008; Elder et al., 2010). In this paper, we follow Jann's (2008) suggestion and take a pooled wage structure (as in Neumark, 1988) that includes an indicator variable for group membership as the non-discriminatory wage structure.

Table 6 reports the changes in relative remuneration across enterprises of different ownership types in urban China by applying the Oaxaca-Blinder decomposition method separately for the years 2002 and 2007. The table presents the mean predictions by ownership group, their difference, and the decomposition of the difference into the explained and the unexplained parts (expressed in both mean value and in percentage of the mean difference).

The top panel in Table 6 shows the log hourly earnings decomposition results by ownership sector for the year 2002. Earnings gaps are rather large, especially between the public sector and PIEs as well as between FIEs and PIEs. In addition, except for the gap between SOEs and FIEs, all of the ownership differences are significantly different from zero. The results of the decomposition reveal that differences in endowment account for a small share of the earnings gap for all pairs of sectors except for the pair UCEs-PIEs, while the unexplained part accounts for most of the observed difference. This pattern corroborates the finding of Démurger et al. (2007a) that segmentation across ownership was fairly serious in urban China in the early 2000s. The most striking example of such segmentation can be observed within the public sector: differences in endowments between SOEs and GAIs are negligible, and the 27 percent earnings gap is almost entirely due to the "unexplained" component, which probably reflects the strong institutional protection of workers in GAIs at the turn of the $21^{\text {st }}$ century. A similar profile can be observed between GAIs and FIEs with the former clearly appearing as a protected sector compared to the foreign sector. The "abnormally" high wages in GAIs can be attributed to incomplete market reforms in institutional regulations. Because GAIs belong to the public services sector, they cannot control production materials and create extra profits. However, many government bureaus have used their privilege to seek rents or even set up their own companies during the transitional period when the role of governments was unclear. The lack of efficient regulations and policies to guide such behaviors may have resulted in abnormally higher incomes in GAIs. 
Compared to the year 2002, the log hourly earnings gaps across ownership in 2007 have narrowed substantially for all pairs of sectors (except between SOEs and FIEs) as well as between GAIs and FIEs for which the gap turned significantly in favor of FIEs. The evolution of these earnings gaps has been generally in favor of both the private and the semi-public sectors (PIEs, FIEs and UCEs) and at the expense of the public sector, especially the GAIs that had profited during the period from 1995 and 2002. As already observed in the descriptive part of the paper, the trend during the period from 2002 to 2007 has been toward a rebalancing between the different types of ownership.

The pattern of decomposition across ownership also changed remarkably between 2002 and 2007 with a striking reversal in contributions of the explained and the unexplained parts in earnings differentials. Differences in endowment gained importance in accounting for earnings gaps in 2007 as well as for the generally decreasing trend in earnings differences across ownership, while segmentation began to be less of an issue.

The decomposition analysis presented in Table 6 highlights three main phenomena on the ownership dimension. These are of importance to understanding the recent evolution of the labor market in urban China. First, both urban collectives and private enterprises have seen their relative position dramatically improve compared to the public sector. Indeed, compared to both SOEs and GAIs, the huge decrease in the earnings gap comes from two concomitant forces: a convergence in endowments and a sharp reduction of segmentation against UCEs and PIEs. This change is important in the sense that it signals better integration of the domestic sectors (public, semi-public or private), which had never before occurred.

The convergence changes observed between the private and the public sectors can be related to the resurgence of private businesses. For a long time, the supply of capital and technologies was comparatively scarce, while the supply of cheap labor was large. These factors made the marginal return on capital and technologies much higher than the return on labor. The comparative advantage of SOEs and FIEs was obvious because they are endowed with sufficient capital and advanced technologies. In recent years, the development of the capital market enabled some private companies to finance sufficient capital and to invest in high technologies in order to attain economies of scale. In addition, the fact that the social burden (e.g., the wages for retired employees) was much smaller for 
the non-public sector than for SOEs also contributed to narrowing wage differences between the public and the private sectors.

Second, although the dominant position of GAIs was diminishing between 2002 and 2007, the still comparatively higher wages in GAIs may be attributed more importantly to employees' better endowments compared to other sectors. This finding is especially true when GAIs are compared to UCEs and PIEs: differences in endowments account respectively for $50 \%$ and $62 \%$ of the earnings gap with GAIs in 2007, while the shares were only $13 \%$ and $30 \%$ in 2002. Put differently, the strong increase in segmentation in favor of GAIs that had been observed in the early 2000s was diminishing during the recent period both in absolute terms and as a share of log earnings differences. This development may indicate a trend toward reduced protection of earnings in public administration.

Third, the foreign sector continued to reinforce its position through both better worker characteristics, as well as more pronounced segmentation, especially as compared to the public sector. Interestingly, the sharp increase in the earnings gap between SOEs and FIEs (in favor of the latter) between 2002 and 2007 comes from both diverging characteristics (which explain almost half the gap in 2007) and increasing segmentation. In 2007, if there were no differences in characteristics with SOEs, the premium for FIEs would be $13 \%$. A similar magnitude of the premium derived from the "unexplained" portion applies to the difference with GAIs, which explains the entire gap because the characteristics of FIE and GAI workers are similar.

With the onset of economic reform, the government issued a number of policies to promote the growth of FIE. For example, FIEs have been granted tax reductions or exemptions, as well as special loan policies, that provided them comparative advantages in cost. However, for a long time, SOEs took advantage by dominating industries (e.g., telecommunication, financing, aviation), monopolizing natural resources and enjoying protection by means of specific policies and regulations. In recent years, the situation has changed and the organizational structures of SOEs became outdated. The lack of institutional transformation and a heavy social burden in the form of hospitals, education and retired workers made the overall profit and corresponding wages in SOEs less attractive except in some oligopolistic sectors.

Finally, compared with UCEs and PIEs, the position of FIEs has not changed significantly: the 
superior worker characteristics in FIEs and a strong segmentation contribute almost equally to a continuation of important earnings gaps of $37 \%$ with UCEs and $47 \%$ with PIEs.

\section{Juhn-Murphy-Pierce decomposition}

The Oaxaca-Blinder decomposition approach only treats the mean of the distribution and ignores differences along the distribution, such as its dispersion or skewness. However, as shown in Section 3, the distribution of hourly earnings differs across sectors. Therefore, to complement the Oaxaca-Blinder decomposition, we use the decomposition technique proposed by Juhn et al., (1993), which takes the whole earnings distribution into account.

The Juhn-Murphy-Pierce decomposition method extends the Oaxaca-Blinder approach by accounting for the residual distribution in order for the hourly earnings gap can be decomposed into three parts: the individual characteristics effect (resulting from a change in the distribution of the $X \mathrm{~s}$ ), the return or "price" effect (resulting from a change in the $\beta$ s) and the residual effect (or unobservable factors' influence).

Following Juhn et al., (1993), the residual $u_{i r}$ in equation (1) can be written as follows:

$$
u_{i r}=F_{r}^{-1}\left(\theta_{i r} \mid X_{i r}\right)
$$

where $\theta_{i r}$ is the percentile of an individual in the residual distribution, and $F_{r}$ is the cumulative distribution function of the earnings equation residuals (for individuals with characteristics $X_{i r}$ in ownership $r$ ).

Assuming that $F^{*}$ is a reference residual distribution and $\beta^{*}$ a reference wage structure, ${ }^{16}$ two hypothetical hourly earnings distribution can be created as follows:

$$
\begin{aligned}
& w_{i r_{1}}^{1}=\beta^{*} X_{i r_{1}}+F^{*-1}\left(\theta_{i r_{1}} \mid X_{i r_{1}}\right) \\
& w_{i r_{1}}^{2}=\beta^{r_{1}} X_{i r_{1}}+F^{*-1}\left(\theta_{i r_{1}} \mid X_{i r_{1}}\right)
\end{aligned}
$$

The first hypothetical set of wages given in equation (6) is computed by valuing each worker's

\footnotetext{
${ }^{16}$ As for the Oaxaca-Blinder decomposition, the reference wage structure is estimated from a pooled model over the whole sample. The reference residual distribution is the average distribution over both samples. Decomposition results presented here are generated using the jmpierce.ado program from Stata.
} 
characteristics $X_{i r_{1}}$ in sector $r_{l}$ at the reference wage structure $\beta^{*}$ and her position in sector $r_{l}$ 's residual distribution at the corresponding position in the reference residual distribution $F^{*}$. The second hypothetical distribution for sector $r_{l}$ provided in equation (7) results from giving each worker her own estimated returns to characteristics $\beta^{r_{1}}$ but to the reference residual distribution $F^{*}$.

The main feature of the Juhn-Murphy-Pierce decomposition approach is that it allows an analysis covering the whole earnings distribution. If the notation $\tilde{w}$ stands for a summary statistic of the distribution of the corresponding variable, one can generate the following decomposition of the log earnings difference between two enterprises of different ownership, $r_{l}$ and $r_{2}$ :

$$
\tilde{w}_{r_{1}}-\tilde{w}_{r_{2}}=\tilde{w}_{r_{1}}^{1}-\tilde{w}_{r_{2}}^{1}+\left[\left(\tilde{w}_{r_{1}}^{2}-\tilde{w}_{r_{2}}^{2}\right)-\left(\tilde{w}_{r_{1}}^{1}-\tilde{w}_{r_{2}}^{1}\right)\right]+\left[\left(\tilde{w}_{r_{1}}-\tilde{w}_{r_{2}}\right)-\left(\tilde{w}_{r_{1}}^{2}-\tilde{w}_{r_{2}}^{2}\right)\right]
$$

Given the definitions above, the first right-hand side term simply reflects the individual characteristics effect or the difference in observable quantities between the two sectors. The second term (into brackets) represents the return effect or the difference in observable prices, and the third term represents the residual effect, which is expressed by the difference of two sectors' residual distributions.

The results of Juhn-Murphy-Pierce decompositions for each pair of ownership are displayed in Figure 2. Each sub-figure presents the earnings gap as well as its decomposition for a pair of ownership types at various percentiles: $5^{\text {th }}, 10^{\text {th }}, 25^{\text {th }}, 50^{\text {th }}, 75^{\text {th }}, 90^{\text {th }}$ and $95^{\text {th }}$. Four main observations can be drawn from these figures.

First, the distribution of earnings gaps varies markedly across pairs of ownership. The comparison of any ownership with the domestic private sector (that is the pairs SOEs-PIEs, GAIs-PIEs, UCEs-PIEs, and FIEs-PIES) shows that the largest gap occurs at the bottom of the distribution, but it almost vanishes at the top of the distribution in both 2002 and 2007. This result means that the significant average earnings gaps observed between these categories of ownership are concentrated in the bottom 5-10 percentile of individuals with the private sector paying much less than any other category. One reason for such difference at the bottom of the wage distribution is that little social welfare is provided in PIEs for low-quantile wage earners, including unemployment insurance and medical insurance. However, the pattern is completely reversed when comparing UCEs and FIEs in 
2002: the earnings gap for the lowest wage-earners is fairly small, and it significantly increases when moving up the income distribution. This result trend reflects the patterns observed in Figure 1 with "high-wage" earners in the foreign sector receiving a much higher remuneration than "high-wage" earners in the semi-public sector in 2002. Finally, the profile for the earning gaps between SOEs and UCEs, between GAIs and UCEs, and between SOEs and GAIs is rather flat in 2002. This indicates comparatively equal distributions of earnings gaps within the public and semi-public sectors with the differences between the top and bottom percentiles not being substantial.

Second, the decomposition of the earnings gaps confirms that individual endowments explain only a small share of the observed gaps within the public and semi-public sectors (SOEs, GAIs, and UCEs), while the price effect is the largest with no significant variations over the distribution. When it comes to a comparison with the private sector, the quantity component becomes relatively more important and explains about half the earnings difference between FIEs and UCEs and between FIEs and PIEs. Finally, the residual effect (unobserved factors) does not play any clear-cut role in explaining earnings difference except at the bottom of the distribution for the pairs SOEs-PIEs, GAIs-PIEs and UCEs-PIEs.

Third, the comparison between SOEs and FIEs deserves specific comments because the gap varies a great deal over the earnings distribution, and important changes occurred over time. In 2002, SOEs were paying comparatively higher wages to low-wage earners, while FIEs were offering higher wages to the $75^{\text {th }}$ percentile, which made the gap change signs over the distribution (and may explain why the mean difference reported in Table 6 is not significant). Interestingly, while the gap in favor of SOEs at the bottom of the distribution appears to be equally explained by differences in quantity, price and residuals, the gap in favor of FIEs at the top of the distribution was mainly explained by different remuneration of characteristics (which more than compensated the superior characteristics of SOEs workers).

Fourth, as previously discussed, earnings differentials have substantially shrunk between 2002 and 2007 for almost all pairs of sectors. Whole distributions provide a more complete view of this average evolution by highlighting some differences along the earnings distribution curve. Hence, the reduction in earnings gap tends to be more pronounced at the bottom of the distribution because of a 
decreasing segmentation. This finding is particularly true for the pairs SOEs-GAIs and UCEs-GAIs, suggesting that in the public sector, the wage structure has become more harmonized for the low-wage earners. In addition, distribution patterns for different ownerships sectors at various percentiles have changed substantially, suggesting that wage-setting mechanisms have experienced considerable changes during this period. In this respect, the foreign sector exhibits particularly interesting changes. Indeed, FIEs have clearly improved their position relative to both SOEs and GAIs with a gap now being fully in favor of FIEs over the whole distribution and with clear differences at the top of the distribution, which are almost fully explained by segmentation in favor of FIEs. This development probably reflects a proactive strategy by FIEs toward high-wage earners (already visible in 2002, although less clear-cut). Interestingly, the smallest earnings differential for the pairs FIEs-SOEs and FIEs-GAIs is around the $25^{\text {th }}$ percentile, which indicates that for individuals below the median, wages across these ownership types are quite similar. Finally, the 2007 graphs also indicate that segmentation still plays a fairly important role in explaining earnings gaps across ownership types with a particularly pronounced importance at the top of the distribution.

\section{Conclusion}

This paper analyzes wages inequality trends across ownership sectors for the period 2002-07 and investigates the mechanisms at stake by decomposing the mean wages difference using the Oaxaca-Blinder technique and analyzing the wages gap distribution through utilization of the Juhn-Murphy-Pierce decomposition method.

We find that while average earnings gaps were still fairly large across ownership sectors in 2002 , they shrank over the ensuing five-year period extending to 2007. Moreover, the observed earnings convergence took place in favor of the private and semi-public sectors as opposed to the public sector. In terms of earnings differentials across the distribution, the Juhn-Murphy-Pierce decomposition highlights a comparatively equal distribution within the public sector, while most of the gap for the private domestic sector comes at the bottom of the distribution. As for foreign-invested enterprises, the clear improvement of their position with regard to the public sector between 2002 and 2007 can be 
observed over the whole distribution, which implies that workers in foreign-invested firms all have benefited from the improved position of these enterprises.

Both the Oaxaca-Blinder and the Juhn-Murphy-Pierce decompositions illustrate that differences in endowments gained importance over time in accounting for earnings gaps as well as for the general decreasing trend in earnings differences across ownership sectors. However, segmentation began to become a less important issue in 2007 compared to 2002. In particular, our results highlight a better integration of domestic sectors that never before occurred. These findings also show that the segmentation in favor of GAIs, which was fairly strong in 2002, has been disappearing over time, although not throughout the whole distribution. Indeed, Juhn-Murphy-Pierce decompositions indicate that segmentation remains important for high-wage earners, which suggests that workers at the top of the distribution are still benefiting from some protection as compared to workers at the low end.

These findings suggest that there are two directions in which the urban labor market in China is moving. The marketization of labor allocation and wage determination is clearly becoming more visible with the process of reforms in the economy as a whole. However, there are clear remaining lines of rigidities, and not all workers are given the same opportunities to benefit from the changes. Our finding that the difference between the public and the private sectors mostly comes from the bottom portion of the distribution clearly points to such a policy issue. In order to achieve a fairer earnings distribution across ownership sectors, a policy goal could be to break the hurdles to entering the public sector for individuals with comparatively inferior characteristics. Moreover, given that we only consider urban locals, we can reasonably expect that the earnings gap that we estimate is in fact a lower bound of the "true" earnings gap if rural migrants were also included. This possibility reinforces the need for alleviating labor mobility obstacles between sectors, industries and areas and improving individuals' overall educational level to reduce access-to-job and earnings inequalities between the bottom and the top of the distribution.

\section{References}

Adamchick, V. A. \& Bedi, A. S. (2000). Wage differentials between the public and the private sectors:

Evidence from an economy in transition. Labour Economics, 7(2), 203-224. 
Appleton, S., Song, L. \& Xia, Q. (2005). Has China crossed the river? The evolution of wage structure in urban China during reform and retrenchment. Journal of Comparative Economics, 33(4), 644-663.

Blinder, A. S. (1973). Wage Discrimination: Reduced Form and Structural Estimates. Journal of Human Resources, 8(4), 436-55.

Brandt, L. \& Holz, C. A. (2006). Spatial Price Differences in China: Estimates and Implications. Economic Development and Cultural Change, 55(1), 43-86.

Card, D. (1999). The causal effect of education on earnings. In Handbook of Labor Economics. Ashenfelter, O. and Card, D. (eds.). North Holland, Amsterdam, 3, 1801-1863.

Chen, Y., Démurger, S. \& Fournier, M. (2005), "Earnings differentials and ownership structure in Chinese enterprises," Economic Development and Cultural Change, 53(4), 933-958.

Démurger, S., Fournier, M. \& Chen, Y. (2007a). The Evolution of Gender Earnings Gaps and Discrimination in Urban China: 1988-1995. The Developing Economies, 45(1), 97-121.

Démurger, S., Fournier, M. Li, S. \& Wei, Z. (2007b). Economic liberalization with rising segmentation on China's urban labor market. Asian Economic Papers, 5(3), 58-101.

Dong, X. \& Bowles, P. (2002). Segmentation and discrimination in China's emerging industrial labor market. China Economic Review, 13(2-3), 170-196.

Elder, T. E., Goddeeris, J. H. \& Haider S. J. (2010). Unexplained gaps and Oaxaca-Blinder decompositions. Labour Economics, 17, 284-290.

Ge, S. \& Yang, D. T. (2010). Accounting for rising wages in China. Working Paper, The Chinese University of Hong Kong.

Gregory, R. \& Borland, J. (1999). Recent developments in public sector labor markets. In Handbook of Labor Economics. Ashenfelter, O. and Card, D. (eds.). North Holland, Amsterdam, 3, 3573-3630.

Jann, B. (2008). Stata implementation of the Blinder-Oaxaca decomposition. ETH Zurich Sociology Working Papers 5, ETH Zurich.

Juhn, C, Murphy, K. \& Pierce, B. (1993). Wage inequality and the rise in returns to skill. Journal of Political Economy, 101, 410-442. 
Knight, J. \& Li, S. (2005). Wages, firm profitability and labor market segmentation in urban China. China Economic Review, 16, 205-228.

Knight, J. \& Song, L. (2003). Increasing urban wage inequality in China: Extent, elements and evaluation. Economics of Transition, 11(4), 597-619.

Leping, K. O. (2006). Evolution of the Public-Private Sector Wage Differential during Transition in Estonia, Post-Communist Economies, 18(4), 419-436.

Li, S. \& Bai, N. (2005). China Human Development Report - Development with Equity. Beijing: UNDP and China Development Research Foundation.

Lokshin, M. M. \& Jovanovic, B. (2003). Wage differentials and state private sector employment choice in Yugoslavia. Economics of Transition, 11(3), 463-491.

Maurer-Fazio, M., Rawski, T. \& Zhang, W. (1999). Inequality in the rewards for holding up half the sky: gender wage gaps in China's urban labor market, 1988-1994. China Journal, 41, 55-88.

Meng, X. (2000). Labour market reform in China. Cambridge, UK: Cambridge University Press.

Mincer, J. (1974). Schooling, experience, and earnings. New York: National Bureau of Economic Research.

National Bureau of Statistics (2008). China Statistical Yearbook. China Statistics Press.

National Bureau of Statistics of China (2010). 2009 Report on migrant workers monitoring survey. http://www.stats.gov.cn/tjfx/fxbg/t20100319_402628281.htm.

Neumark, D. (1988). Employers' Discriminatory Behavior and the Estimation of Wage Discrimination. The Journal of Human Resources, 23, 279-295.

Oaxaca, R. L. (1973). Male-Female Wage Differentials in Urban Labor Markets. International Economic Review, 14(3), 693-709.

Song, J. \& Li, S. (2010). Changes in gender wage gap in urban China during 1995-2007. Conference paper for the inequality workshop, BNU, China.

Xing, C. (2008). Human Capital and Wage Determination in Different Ownerships, 1989-97. In Understanding Inequality and Poverty in China: Methods and Applications. Wan, G. (ed.). Palgrave Macmillan.

Xing, C. (2010). Residual Wage Inequality in Urban China, 1995-2007. IZA Discussion Paper No. 
5003.

Zhao, Y. (2002). Earnings differentials between state and non-state enterprises in urban China. Pacific Economic Review, 7(1), 181-197.

Table 1 - Definition of ownership categories

\begin{tabular}{|c|c|c|}
\hline $\begin{array}{l}\text { Public versus private } \\
\text { groups }\end{array}$ & Ownership categories & Types included \\
\hline \multirow[t]{2}{*}{ Public sector } & State-owned enterprises (SOEs) & $\begin{array}{l}\text { Solely state-owned enterprises; } \\
\text { State holding enterprises; } \\
\text { State holding joint venture. }\end{array}$ \\
\hline & $\begin{array}{l}\text { Government agencies and } \\
\text { institutions (GAIs) }\end{array}$ & $\begin{array}{l}\text { Government agencies and Party agencies } \\
\text { (including the Party Committee, Government, } \\
\text { People's Congress, the Chinese People's Political } \\
\text { Consultative Conference (CPPCC), Public security } \\
\text { organs and procurator's offices and courts, the } \\
\text { Ministry of Armed Forces, the Army); } \\
\text { State and collective institutions; } \\
\text { Civilian-run enterprises and public service unit. }\end{array}$ \\
\hline Semi-public sector & $\begin{array}{l}\text { Urban collective enterprises } \\
\text { (UCEs) }\end{array}$ & $\begin{array}{l}\text { Solely collective-owned enterprise; } \\
\text { Collective holding enterprises; } \\
\text { Collective holding joint venture. }\end{array}$ \\
\hline \multirow[t]{2}{*}{ Private sector } & $\begin{array}{l}\text { Private and individual } \\
\text { enterprises (PIEs) }\end{array}$ & $\begin{array}{l}\text { Solely private-owned enterprises; } \\
\text { Private holding enterprises; } \\
\text { Private holding joint venture; } \\
\text { Self-employed Individuals. }\end{array}$ \\
\hline & $\begin{array}{l}\text { Foreign-invested enterprises } \\
\text { (FIEs) }\end{array}$ & $\begin{array}{l}\text { Solely foreign-owned enterprises; } \\
\text { Foreign holding joint venture. }\end{array}$ \\
\hline
\end{tabular}

Source: RUMIC-2007 urban survey questionnaire.

Note: if the answer given by the respondent is "Other enterprises," then it is not attributed to any of the above category and is simply dropped. 
Table 2 - Descriptive statistics on individual characteristics by ownership

\begin{tabular}{|c|c|c|c|c|c|c|}
\hline 2002 & SOEs & GAIs & UCES & PIEs & FIEs & All \\
\hline Male & $\begin{array}{c}0.595 \\
(0.491)\end{array}$ & $\begin{array}{c}0.547 \\
(0.498)\end{array}$ & $\begin{array}{c}0.439 \\
(0.497)\end{array}$ & $\begin{array}{c}0.549 \\
(0.498)\end{array}$ & $\begin{array}{c}0.567 \\
(0.497)\end{array}$ & $\begin{array}{c}0.557 \\
(0.497)\end{array}$ \\
\hline Age & $\begin{array}{c}40.88 \\
(8.522)\end{array}$ & $\begin{array}{c}40.56 \\
(8.971)\end{array}$ & $\begin{array}{c}41.47 \\
(8.200)\end{array}$ & $\begin{array}{c}39.14 \\
(8.688)\end{array}$ & $\begin{array}{c}35.85 \\
(8.923)\end{array}$ & $\begin{array}{c}40.28 \\
(8.748)\end{array}$ \\
\hline Education & $\begin{array}{c}11.17 \\
(2.704)\end{array}$ & $\begin{array}{c}12.68 \\
(2.870)\end{array}$ & $\begin{array}{c}10.14 \\
(2.470)\end{array}$ & $\begin{array}{c}10.14 \\
(2.865)\end{array}$ & $\begin{array}{c}11.96 \\
(2.665)\end{array}$ & $\begin{array}{c}11.34 \\
(2.959)\end{array}$ \\
\hline Experience in current job & $\begin{array}{c}17.72 \\
(9.385)\end{array}$ & $\begin{array}{c}14.45 \\
(9.229)\end{array}$ & $\begin{array}{c}16.22 \\
(9.395)\end{array}$ & $\begin{array}{c}10.44 \\
(9.333)\end{array}$ & $\begin{array}{c}10.46 \\
(8.417)\end{array}$ & $\begin{array}{c}14.66 \\
(9.729)\end{array}$ \\
\hline Training & $\begin{array}{c}0.284 \\
(0.451)\end{array}$ & $\begin{array}{c}0.325 \\
(0.468)\end{array}$ & $\begin{array}{c}0.241 \\
(0.428)\end{array}$ & $\begin{array}{c}0.197 \\
(0.398)\end{array}$ & $\begin{array}{c}0.276 \\
(0.449)\end{array}$ & $\begin{array}{c}0.272 \\
(0.445)\end{array}$ \\
\hline Coast & $\begin{array}{c}0.308 \\
(0.462)\end{array}$ & $\begin{array}{c}0.293 \\
(0.455)\end{array}$ & $\begin{array}{c}0.452 \\
(0.498)\end{array}$ & $\begin{array}{c}0.363 \\
(0.481)\end{array}$ & $\begin{array}{c}0.504 \\
(0.502)\end{array}$ & $\begin{array}{c}0.332 \\
(0.471)\end{array}$ \\
\hline Capital city & $\begin{array}{c}0.348 \\
(0.476)\end{array}$ & $\begin{array}{c}0.306 \\
(0.461)\end{array}$ & $\begin{array}{c}0.234 \\
(0.424)\end{array}$ & $\begin{array}{c}0.236 \\
(0.425)\end{array}$ & $\begin{array}{c}0.488 \\
(0.502)\end{array}$ & $\begin{array}{c}0.303 \\
(0.460)\end{array}$ \\
\hline $\begin{array}{c}\text { Observations } \\
\% \text { of total }\end{array}$ & $\begin{array}{l}1,899 \\
34.87\end{array}$ & $\begin{array}{l}1,708 \\
31.36\end{array}$ & $\begin{array}{l}394 \\
7.23\end{array}$ & $\begin{array}{l}1,318 \\
24.20\end{array}$ & $\begin{array}{l}127 \\
2.33\end{array}$ & $\begin{array}{c}5,446 \\
100.00\end{array}$ \\
\hline 2007 & SOEs & GAIs & UCEs & PIEs & FIEs & All \\
\hline Male & $\begin{array}{c}0.614 \\
(0.487)\end{array}$ & $\begin{array}{c}0.566 \\
(0.496)\end{array}$ & $\begin{array}{c}0.537 \\
(0.500)\end{array}$ & $\begin{array}{c}0.552 \\
(0.497)\end{array}$ & $\begin{array}{c}0.558 \\
(0.498)\end{array}$ & $\begin{array}{c}0.569 \\
(0.495)\end{array}$ \\
\hline Age & $\begin{array}{c}40.59 \\
(9.283)\end{array}$ & $\begin{array}{c}40.70 \\
(9.395)\end{array}$ & $\begin{array}{c}39.52 \\
(9.118)\end{array}$ & $\begin{array}{c}38.02 \\
(9.312)\end{array}$ & $\begin{array}{c}34.17 \\
(7.748)\end{array}$ & $\begin{array}{c}39.51 \\
(9.409)\end{array}$ \\
\hline Education & $\begin{array}{c}12.14 \\
(3.034)\end{array}$ & $\begin{array}{c}12.98 \\
(3.075)\end{array}$ & $\begin{array}{c}11.78 \\
(3.116)\end{array}$ & $\begin{array}{c}11.29 \\
(3.231)\end{array}$ & $\begin{array}{c}13.39 \\
(3.211)\end{array}$ & $\begin{array}{c}12.21 \\
(3.215)\end{array}$ \\
\hline Experience in current job & $\begin{array}{c}16.97 \\
(10.72)\end{array}$ & $\begin{array}{c}14.89 \\
(10.67)\end{array}$ & $\begin{array}{c}12.48 \\
(10.19)\end{array}$ & $\begin{array}{c}8.610 \\
(8.127)\end{array}$ & $\begin{array}{c}8.628 \\
(7.126)\end{array}$ & $\begin{array}{c}12.87 \\
(10.34)\end{array}$ \\
\hline Training & $\begin{array}{c}0.442 \\
(0.497)\end{array}$ & $\begin{array}{c}0.424 \\
(0.494)\end{array}$ & $\begin{array}{c}0.326 \\
(0.470)\end{array}$ & $\begin{array}{c}0.274 \\
(0.446)\end{array}$ & $\begin{array}{c}0.407 \\
(0.493)\end{array}$ & $\begin{array}{c}0.372 \\
(0.483)\end{array}$ \\
\hline Coast & $\begin{array}{c}0.248 \\
(0.432)\end{array}$ & $\begin{array}{c}0.322 \\
(0.467)\end{array}$ & $\begin{array}{c}0.389 \\
(0.488)\end{array}$ & $\begin{array}{c}0.397 \\
(0.489)\end{array}$ & $\begin{array}{c}0.628 \\
(0.485)\end{array}$ & $\begin{array}{c}0.347 \\
(0.476)\end{array}$ \\
\hline Capital city & $\begin{array}{c}0.672 \\
(0.470)\end{array}$ & $\begin{array}{c}0.663 \\
(0.473)\end{array}$ & $\begin{array}{c}0.646 \\
(0.479)\end{array}$ & $\begin{array}{c}0.606 \\
(0.489)\end{array}$ & $\begin{array}{c}0.512 \\
(0.501)\end{array}$ & $\begin{array}{c}0.640 \\
(0.480)\end{array}$ \\
\hline Observations & 951 & 1,981 & 285 & 1,662 & 172 & 5,051 \\
\hline$\%$ of total & 18.83 & 39.22 & 5.64 & 32.90 & 3.41 & 100.00 \\
\hline
\end{tabular}

Source: Authors' calculations using the CHIP-2002 and RUMIC-2007 survey data, urban sample, seven provinces data, for full-time employed individuals aged 16 to 60 earning positive wages.

Note: Ownership categories are state-owned enterprises (SOEs), government agencies or institutions (GAIs), urban collective enterprises (UCEs), private or individual enterprises (PIEs), and foreign-invested enterprises (FIEs). "Experience in current job" stands for the number of years in the current occupation. 
Table 3 - Descriptive statistics on individual earnings by ownership

\begin{tabular}{|c|c|c|c|c|c|c|}
\hline 2002 & SOEs & GAIs & UCES & PIEs & FIEs & All \\
\hline Total yearly income & $\begin{array}{c}11,253 \\
(7,350)\end{array}$ & $\begin{array}{l}14,192 \\
(7,992)\end{array}$ & $\begin{array}{c}8,100 \\
(4,878)\end{array}$ & $\begin{array}{c}9,263 \\
(9,153)\end{array}$ & $\begin{array}{c}12,908 \\
(9,618)\end{array}$ & $\begin{array}{c}11,504 \\
(8,208)\end{array}$ \\
\hline Gap to average earnings & 0.98 & 1.23 & 0.70 & 0.81 & 1.12 & \\
\hline Gini coefficient & 0.307 & 0.290 & 0.293 & 0.387 & 0.324 & 0.336 \\
\hline Working hours/week & $\begin{array}{c}42.3 \\
(7.97)\end{array}$ & $\begin{array}{l}41.24 \\
(8.05)\end{array}$ & $\begin{array}{c}44.37 \\
(10.38)\end{array}$ & $\begin{array}{c}51.9 \\
(15.65)\end{array}$ & $\begin{array}{c}45.34 \\
(11.61)\end{array}$ & $\begin{array}{c}44.51 \\
(11.44)\end{array}$ \\
\hline Hourly wage & $\begin{array}{c}5.376 \\
(4.373)\end{array}$ & $\begin{array}{c}7.070 \\
(6.086)\end{array}$ & $\begin{array}{c}3.706 \\
(2.442)\end{array}$ & $\begin{array}{c}3.849 \\
(4.815)\end{array}$ & $\begin{array}{c}5.877 \\
(4.836)\end{array}$ & $\begin{array}{c}5.429 \\
(5.151)\end{array}$ \\
\hline Gap to average earnings & 0.99 & 1.30 & 0.68 & 0.71 & 1.08 & \\
\hline Gini coefficient & 0.334 & 0.329 & 0.322 & 0.430 & 0.361 & 0.377 \\
\hline Observations & 1,899 & 1,708 & 394 & 1,318 & 127 & 5,446 \\
\hline 2007 & SOES & GAIs & UCEs & PIEs & FIEs & All \\
\hline Total yearly income & $\begin{array}{c}21,604 \\
(18,188)\end{array}$ & $\begin{array}{c}23,042 \\
(16,223)\end{array}$ & $\begin{array}{c}18,897 \\
(12,957)\end{array}$ & $\begin{array}{c}20,430 \\
(27,224)\end{array}$ & $\begin{array}{c}27,456 \\
(19,756)\end{array}$ & $\begin{array}{c}21,828 \\
(20,848)\end{array}$ \\
\hline Gap to average earnings & 0.99 & 1.06 & 0.87 & 0.94 & 1.26 & \\
\hline Gini coefficient & 0.341 & 0.339 & 0.337 & 0.409 & 0.366 & 0.367 \\
\hline 2002-07 growth rate & $92 \%$ & $62 \%$ & $133 \%$ & $121 \%$ & $113 \%$ & $90 \%$ \\
\hline Working hours/week & $\begin{array}{l}43.23 \\
(9.67)\end{array}$ & $\begin{array}{c}42.19 \\
(19.15)\end{array}$ & $\begin{array}{c}44.65 \\
(10.24)\end{array}$ & $\begin{array}{c}49.89 \\
(22.32)\end{array}$ & $\begin{array}{l}42.61 \\
(7.72)\end{array}$ & $\begin{array}{c}45.07 \\
(18.57)\end{array}$ \\
\hline Hourly wage & $\begin{array}{c}10.13 \\
(9.023)\end{array}$ & $\begin{array}{c}11.55 \\
(10.99)\end{array}$ & $\begin{array}{c}8.826 \\
(6.914)\end{array}$ & $\begin{array}{c}8.92 \\
(11.55)\end{array}$ & $\begin{array}{c}12.81 \\
(9.277)\end{array}$ & $\begin{array}{c}10.31 \\
(10.66)\end{array}$ \\
\hline Gap to average earnings & 0.98 & 1.12 & 0.86 & 0.87 & 1.24 & \\
\hline Gini coefficient & 0.364 & 0.379 & 0.375 & 0.449 & 0.375 & 0.406 \\
\hline 2002-07 growth rate & $88 \%$ & $63 \%$ & $138 \%$ & $132 \%$ & $118 \%$ & $90 \%$ \\
\hline Observations & 951 & 1,981 & 285 & 1,662 & 172 & 5,051 \\
\hline
\end{tabular}

Source: see Table 2 .

Notes: Earnings are deflated using the urban provincial-level spatial price deflators calculated by Brandt and Holz (2006) and are updated for the year 2007. Base: nationwide prices in 2002. 
Table 4 - Hourly wage functions by ownership, 2002

\begin{tabular}{|c|c|c|c|c|c|}
\hline & $\begin{array}{c}(1) \\
\text { SOEs }\end{array}$ & $\begin{array}{c}(2) \\
\text { GAIs }\end{array}$ & $\begin{array}{c}(3) \\
\text { UCEs }\end{array}$ & $\begin{array}{c}(4) \\
\text { PIEs }\end{array}$ & $\begin{array}{c}(5) \\
\text { FIEs }\end{array}$ \\
\hline \multirow[t]{2}{*}{ Male } & $0.115^{* * *}$ & $0.0805^{* * * *}$ & $0.129^{* *}$ & $0.215^{* * *}$ & 0.160 \\
\hline & $(0.0268)$ & $(0.0279)$ & $(0.0592)$ & $(0.0503)$ & $(0.113)$ \\
\hline \multirow[t]{2}{*}{ Education } & $0.0612^{* * *}$ & $0.0653^{* * *}$ & $0.0553^{* * *}$ & $0.0795^{* * *}$ & $0.0910^{* * *}$ \\
\hline & $(0.00565)$ & $(0.00577)$ & $(0.0117)$ & $(0.0109)$ & $(0.0209)$ \\
\hline \multirow[t]{2}{*}{ Experience } & $0.0367^{* * *}$ & $0.0428^{* * *}$ & 0.0222 & $0.0365^{* * *}$ & 0.0241 \\
\hline & $(0.00674)$ & $(0.00701)$ & $(0.0145)$ & $(0.00898)$ & $(0.0226)$ \\
\hline \multirow[t]{2}{*}{ Experience $^{2}$} & $-0.000607^{\text {*** }}$ & $-0.000759^{* * *}$ & -0.000400 & $-0.000622^{* * *}$ & -0.000306 \\
\hline & $(0.000137)$ & $(0.000150)$ & $(0.000280)$ & $(0.000189)$ & $(0.000530)$ \\
\hline \multirow{2}{*}{$\begin{array}{l}\text { Experience in } \\
\text { current job }\end{array}$} & $0.00429^{* *}$ & $0.0148^{* * *}$ & 0.00201 & $0.0196^{* * *}$ & $0.0129^{*}$ \\
\hline & $(0.00218)$ & $(0.00187)$ & $(0.00355)$ & $(0.00252)$ & $(0.00740)$ \\
\hline \multirow[t]{2}{*}{ Training } & $0.200^{* * * *}$ & 0.0412 & 0.0809 & 0.101 & 0.186 \\
\hline & $(0.0281)$ & (0.0299) & $(0.0654)$ & $(0.0660)$ & $(0.147)$ \\
\hline \multirow[t]{2}{*}{ Coast } & $0.200^{* * *}$ & $0.340^{* * *}$ & $0.154^{* *}$ & $0.408^{* * *}$ & 0.138 \\
\hline & $(0.0291)$ & $(0.0305)$ & $(0.0594)$ & $(0.0463)$ & $(0.136)$ \\
\hline \multirow[t]{2}{*}{ Capital city } & $0.208^{* * *}$ & 0.0439 & $0.315^{* * *}$ & $0.268^{* * *}$ & 0.0827 \\
\hline & $(0.0271)$ & $(0.0298)$ & $(0.0654)$ & $(0.0548)$ & $(0.136)$ \\
\hline \multirow[t]{2}{*}{ Constant } & -0.00216 & 0.0490 & 0.0541 & $-0.836^{* * *}$ & -0.232 \\
\hline & $(0.104)$ & $(0.109)$ & $(0.236)$ & $(0.178)$ & $(0.362)$ \\
\hline$N$ & 1,899 & 1,708 & 394 & 1,318 & 127 \\
\hline$R^{2}$ & 0.191 & 0.252 & 0.150 & 0.189 & 0.188 \\
\hline
\end{tabular}

Source: see Table 2.

Notes: see Table 2. Standard errors in parentheses. ${ }^{*} p<0.10,{ }^{* *} p<0.05,{ }^{* * *} p<0.01$. Earnings are deflated using the urban provincial-level spatial price deflators calculated by Brandt and Holz (2006) and are updated for the year 2007. Base: nationwide prices in 2002. 
Table 5 - Hourly wage functions by ownership, 2007

\begin{tabular}{lccccc}
\hline & $(1)$ & $(2)$ & $(3)$ & $(4)$ & $(5)$ \\
& SOEs & GAIs & UCEs & PIEs & FIEs \\
\hline Gender & $0.194^{* * * *}$ & $0.183^{* * * *}$ & $0.211^{* * * *}$ & $0.258^{* * * *}$ & 0.0632 \\
Education & $(0.0457)$ & $(0.0294)$ & $(0.0755)$ & $(0.0350)$ & $(0.0908)$ \\
& $0.0383^{* * *}$ & $0.0709^{* * * *}$ & $0.0663^{* * * *}$ & $0.0504^{* * * *}$ & $0.0907^{* * * *}$ \\
Experience & $(0.0103)$ & $(0.00702)$ & $(0.0162)$ & $(0.00704)$ & $(0.0225)$ \\
& $0.0166^{* *}$ & $0.0129^{* * *}$ & -0.00337 & $0.0142^{* *}$ & 0.0184 \\
Experience & $(0.00844)$ & $(0.00650)$ & $(0.0142)$ & $(0.00624)$ & $(0.0243)$ \\
& $-0.000444^{* * * *}$ & $-0.000388^{* * *}$ & -0.0000325 & $-0.000484^{* * *}$ & -0.000606 \\
Experience in & $(0.000171)$ & $(0.000142)$ & $(0.000301)$ & $(0.000145)$ & $(0.000619)$ \\
current job & $0.00793^{* * * *}$ & $0.0225^{* * *}$ & 0.00620 & $0.0130^{* * * *}$ & $0.0317^{* * * *}$ \\
Training & $(0.00267)$ & $(0.00193)$ & $(0.00449)$ & $(0.00234)$ & $(0.00842)$ \\
& $0.199^{* * *}$ & 0.0431 & 0.120 & $0.103^{* * *}$ & 0.0932 \\
Coast & $(0.0441)$ & $(0.0303)$ & $(0.0818)$ & $(0.0367)$ & $(0.0927)$ \\
& $0.341^{* * *}$ & $0.334^{* * *}$ & $0.270^{* * *}$ & $0.385^{* * *}$ & $0.229^{* *}$ \\
Capital city & $(0.0564)$ & $(0.0303)$ & $(0.0693)$ & $(0.0355)$ & $(0.116)$ \\
& $0.0766^{* *}$ & $0.0723^{* * *}$ & $0.187^{* *}$ & $0.182^{* * *}$ & -0.106 \\
Constant & $(0.0434)$ & $(0.0300)$ & $(0.0767)$ & $(0.0363)$ & $(0.103)$ \\
& $1.041^{* * *}$ & $0.607^{* * *}$ & $0.802^{* * *}$ & $0.699^{* * *}$ & 0.571 \\
$N$ & $(0.191)$ & $(0.125)$ & $(0.302)$ & $(0.121)$ & $(0.434)$ \\
$R^{2}$ & 950 & 1977 & 285 & 1659 & 172 \\
\hline Source: & 0.136 & 0.244 & 0.210 & 0.201 & 0.329 \\
\hline
\end{tabular}

Source: see Table 2.

Notes: see Table 4. 
Table 6 - Oaxaca-Blinder decomposition of log hourly wages by ownership

\begin{tabular}{|c|c|c|c|c|c|c|c|c|}
\hline \multicolumn{9}{|l|}{ ear 2002} \\
\hline & \multicolumn{2}{|c|}{$\begin{array}{c}\text { Average log } \\
\text { earnings }\end{array}$} & \multirow[t]{2}{*}{$\begin{array}{l}\text { Difference } \\
(\mathrm{A}-\mathrm{B})\end{array}$} & \multicolumn{4}{|c|}{ Decomposition } & \multirow[t]{2}{*}{$\mathrm{N}$} \\
\hline & Group A & Group B & & Explained & Percentage & Unexplained & Percentage & \\
\hline \multirow[t]{2}{*}{ SOEs-GAIs } & $1.490^{* * *}$ & $1.758^{* * *}$ & $-0.268^{* * *}$ & $-0.0326^{* *}$ & $12.2 \%$ & $-0.236^{* * *}$ & $87.8 \%$ & 3,607 \\
\hline & $(0.0141)$ & $(0.0155)$ & $(0.0209)$ & $(0.0118)$ & & $(0.0199)$ & & \\
\hline \multirow[t]{2}{*}{ SOEs-UCEs } & $1.490^{* * *}$ & $1.138^{* * * *}$ & $0.351^{* * * *}$ & $0.0760^{* * *}$ & $21.7 \%$ & $0.275^{* * * *}$ & $78.3 \%$ & 2,293 \\
\hline & $(0.0141)$ & $(0.0292)$ & $(0.0324)$ & $(0.0155)$ & & $(0.0312)$ & & \\
\hline \multirow[t]{2}{*}{ SOEs-PIEs } & $1.490^{* * *}$ & $0.973^{* * *}$ & $0.516^{* * * *}$ & $0.193^{* * *}$ & $37.4 \%$ & $0.324^{* * * *}$ & $62.6 \%$ & 3,217 \\
\hline & $(0.0141)$ & $(0.0265)$ & (0.0300) & $(0.0163)$ & & $(0.0281)$ & & \\
\hline \multirow[t]{2}{*}{ SOEs-FIEs } & $1.490^{* * *}$ & $1.547^{* * * *}$ & -0.0574 & -0.00964 & $16.8 \%$ & -0.0478 & $83.2 \%$ & 2,026 \\
\hline & $(0.0141)$ & $(0.0587)$ & (0.0604) & $(0.0257)$ & & $(0.0562)$ & & \\
\hline \multirow[t]{2}{*}{ GAIs-UCEs } & $1.758^{* * *}$ & $1.138^{* * *}$ & $0.620^{* * * *}$ & $0.0796^{* * *}$ & $12.8 \%$ & $0.540^{* * * *}$ & $87.2 \%$ & 2,102 \\
\hline & $(0.0155)$ & $(0.0292)$ & (0.0331) & $(0.0200)$ & & $(0.0340)$ & & \\
\hline \multirow[t]{2}{*}{ GAIs-PIEs } & $1.758^{* * * *}$ & $0.973^{* * *}$ & $0.785^{* * * *}$ & $0.233^{* * *}$ & $29.7 \%$ & $0.551^{* * * *}$ & $70.3 \%$ & 3,026 \\
\hline & $(0.0155)$ & $(0.0265)$ & $(0.0307)$ & $(0.0191)$ & & $(0.0303)$ & & \\
\hline \multirow[t]{2}{*}{ GAIs-FIEs } & $1.758^{* * *}$ & $1.547^{* * * *}$ & $0.211^{* * * *}$ & $0.0764^{* * *}$ & $36.2 \%$ & $0.135^{*}$ & $63.8 \%$ & 1,835 \\
\hline & $(0.0155)$ & $(0.0587)$ & $(0.0607)$ & $(0.0279)$ & & $(0.0582)$ & & \\
\hline \multirow[t]{2}{*}{ UCEs-PIEs } & $1.138^{* * *}$ & $0.973^{* * *}$ & $0.165^{* * * *}$ & $0.128^{* * * *}$ & $77.6 \%$ & 0.0374 & $22.4 \%$ & 1,712 \\
\hline & $(0.0292)$ & $(0.0265)$ & $(0.0395)$ & $(0.0240)$ & & $(0.0370)$ & & \\
\hline \multirow[t]{2}{*}{ UCEs-FIEs } & $1.138^{* * * *}$ & $1.547^{* * *}$ & $-0.408^{* * *}$ & $-0.130^{* * *}$ & $31.9 \%$ & $-0.278^{* * *}$ & $68.1 \%$ & 521 \\
\hline & $(0.0293)$ & $(0.0588)$ & $(0.0656)$ & $(0.0385)$ & & & & \\
\hline \multirow[t]{2}{*}{ PIEs-FIEs } & $0.973^{* * *}$ & $1.547^{* * * *}$ & $-0.574^{* * *}$ & $-0.227^{* * *}$ & $39.5 \%$ & $-0.347^{* * * *}$ & $60.5 \%$ & 1,445 \\
\hline & $(0.0265)$ & $(0.0587)$ & $(0.0644)$ & $(0.0381)$ & & $(0.0608)$ & & \\
\hline
\end{tabular}


Table 6 (cont') - Oaxaca-Blinder decomposition of log hourly wages by ownership

Year 2007

\begin{tabular}{|c|c|c|c|c|c|c|c|c|}
\hline & \multicolumn{2}{|c|}{$\begin{array}{c}\text { Average log } \\
\text { earnings }\end{array}$} & \multirow[t]{2}{*}{$\begin{array}{l}\text { Difference } \\
\text { (A-B) }\end{array}$} & \multicolumn{4}{|c|}{ Decomposition } & \multirow[t]{2}{*}{$\mathrm{N}$} \\
\hline & Group A & Group B & & Explained & Percentage & Unexplained & Percentage & \\
\hline SOEs-GAIs & $\begin{array}{l}2.081^{* * *} \\
(0.0232)\end{array}$ & $\begin{array}{l}2.190^{* * *} \\
(0.0162)\end{array}$ & $\begin{array}{l}-0.109^{* * *} \\
(0.0283)\end{array}$ & $\begin{array}{l}-0.0262 \\
(0.0140)\end{array}$ & $24.0 \%$ & $\begin{array}{c}-0.0828^{* *} \\
(0.0283)\end{array}$ & $76.0 \%$ & 2,927 \\
\hline SOEs-UCEs & $\begin{array}{l}2.081^{* * *} \\
(0.0232)\end{array}$ & $\begin{array}{l}1.946^{* * *} \\
(0.0394)\end{array}$ & $\begin{array}{c}0.135^{* *} \\
(0.0458)\end{array}$ & $\begin{array}{l}0.0428^{*} \\
(0.0209)\end{array}$ & $31.7 \%$ & $\begin{array}{c}0.0922^{*} \\
(0.0446)\end{array}$ & $68.3 \%$ & 1,235 \\
\hline SOEs-PIEs & $\begin{array}{l}2.081^{* * *} \\
(0.0232)\end{array}$ & $\begin{array}{l}1.841^{* * *} \\
(0.0191)\end{array}$ & $\begin{array}{l}0.240^{* * *} \\
(0.0301)\end{array}$ & $\begin{array}{l}0.121^{* * *} \\
(0.0191)\end{array}$ & $50.4 \%$ & $\begin{array}{l}0.118^{* * *} \\
(0.0314)\end{array}$ & $49.6 \%$ & 2,609 \\
\hline SOEs-FIEs & $\begin{array}{l}2.081^{* * *} \\
(0.0232)\end{array}$ & $\begin{array}{l}2.312^{* * *} \\
(0.0532)\end{array}$ & $\begin{array}{l}-0.231^{* * *} \\
(0.0581)\end{array}$ & $\begin{array}{l}-0.0987^{* *} \\
(0.0332)\end{array}$ & $42.7 \%$ & $\begin{array}{l}-0.133^{*} \\
(0.0596)\end{array}$ & $57.3 \%$ & 1,122 \\
\hline GAIs-UCEs & $\begin{array}{l}2.190^{* * *} \\
(0.0162)\end{array}$ & $\begin{array}{l}1.946^{* * *} \\
(0.0394)\end{array}$ & $\begin{array}{l}0.244^{* * *} \\
(0.0426)\end{array}$ & $\begin{array}{l}0.123^{* * *} \\
(0.0224)\end{array}$ & $50.4 \%$ & $\begin{array}{l}0.121^{* *} \\
(0.0399)\end{array}$ & $49.6 \%$ & 2,262 \\
\hline GAIs-PIEs & $\begin{array}{l}2.190^{* * *} \\
(0.0162)\end{array}$ & $\begin{array}{l}1.841^{* * *} \\
(0.0191)\end{array}$ & $\begin{array}{l}0.349^{* * *} \\
(0.0250)\end{array}$ & $\begin{array}{l}0.217^{\text {*** }} \\
(0.0158)\end{array}$ & $62.2 \%$ & $\begin{array}{l}0.132^{* * *} \\
(0.0242)\end{array}$ & $37.8 \%$ & 3,636 \\
\hline GAIs-FIEs & $\begin{array}{l}2.190^{* * *} \\
(0.0162)\end{array}$ & $\begin{array}{l}2.312^{* * *} \\
(0.0532)\end{array}$ & $\begin{array}{c}-0.122^{*} \\
(0.0556)\end{array}$ & $\begin{array}{r}-0.00173 \\
(0.0304)\end{array}$ & $1.4 \%$ & $\begin{array}{c}-0.121^{*} \\
(0.0488)\end{array}$ & $98.6 \%$ & 2,149 \\
\hline UCEs-PIEs & $\begin{array}{l}1.946^{* * *} \\
(0.0394)\end{array}$ & $\begin{array}{l}1.841^{* * *} \\
(0.0191)\end{array}$ & $\begin{array}{c}0.105^{*} \\
(0.0438)\end{array}$ & $\begin{array}{l}0.0748^{* * *} \\
(0.0219)\end{array}$ & $71.2 \%$ & $\begin{array}{c}0.0299 \\
(0.0400)\end{array}$ & $28.8 \%$ & 1,944 \\
\hline UCEs-FIEs & $\begin{array}{l}1.946^{* * *} \\
(0.0395)\end{array}$ & $\begin{array}{l}2.312^{* * *} \\
(0.0532)\end{array}$ & $\begin{array}{l}-0.366^{* * *} \\
(0.0663)\end{array}$ & $\begin{array}{l}-0.179^{* * *} \\
(0.0404)\end{array}$ & $48.9 \%$ & $\begin{array}{l}-0.188^{* *} \\
(0.0643)\end{array}$ & $51.1 \%$ & 457 \\
\hline PIEs-FIEs & $\begin{array}{l}1.841^{* * *} \\
(0.0191)\end{array}$ & $\begin{array}{l}2.312^{* * *} \\
(0.0532)\end{array}$ & $\begin{array}{l}-0.471^{\text {*** }} \\
(0.0565)\end{array}$ & $\begin{array}{l}-0.237^{* * *} \\
(0.0290)\end{array}$ & $50.3 \%$ & $\begin{array}{l}-0.234^{* * *} \\
(0.0510)\end{array}$ & $49.7 \%$ & 1,831 \\
\hline
\end{tabular}

Source: see Table 2.

Notes: see Table 2. Standard errors in parentheses. ${ }^{*} p<0.05,{ }^{* *} p<0.01,{ }^{* * *} p<0.001$. Decompositions based on regressions results presented in Tables 4 and 5. Earnings are deflated using the urban provincial-level spatial price deflators calculated by Brandt and Holz (2006) and are updated for the year 2007. Base: nationwide prices in 2002. 
Figure 1 - Kernel density estimations for the distribution of income by ownership category, 2002 and 2007

Kernel density of hourly earnings by ownership, 2002

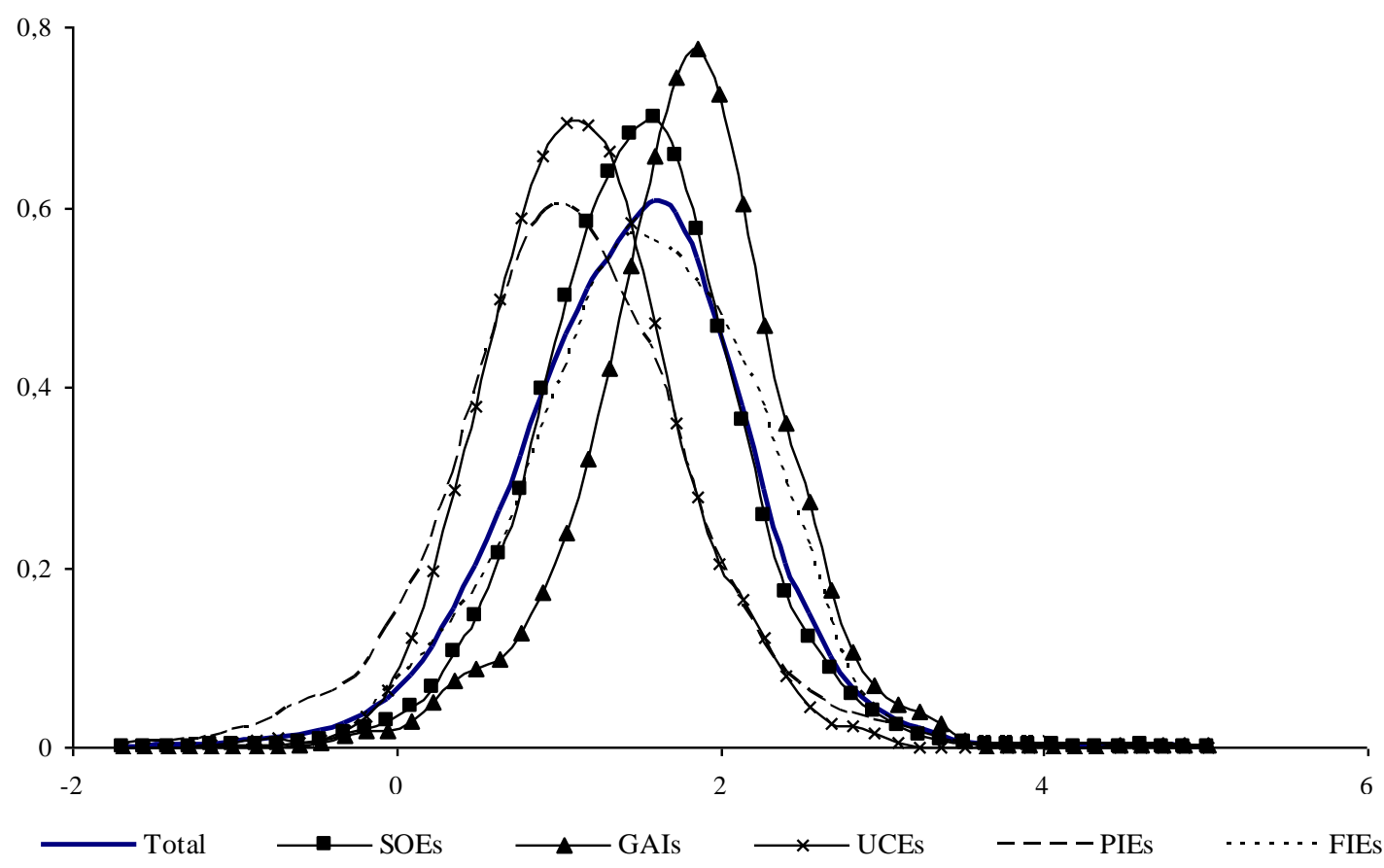

Kernel density of hourly earnings by ownership, 2007

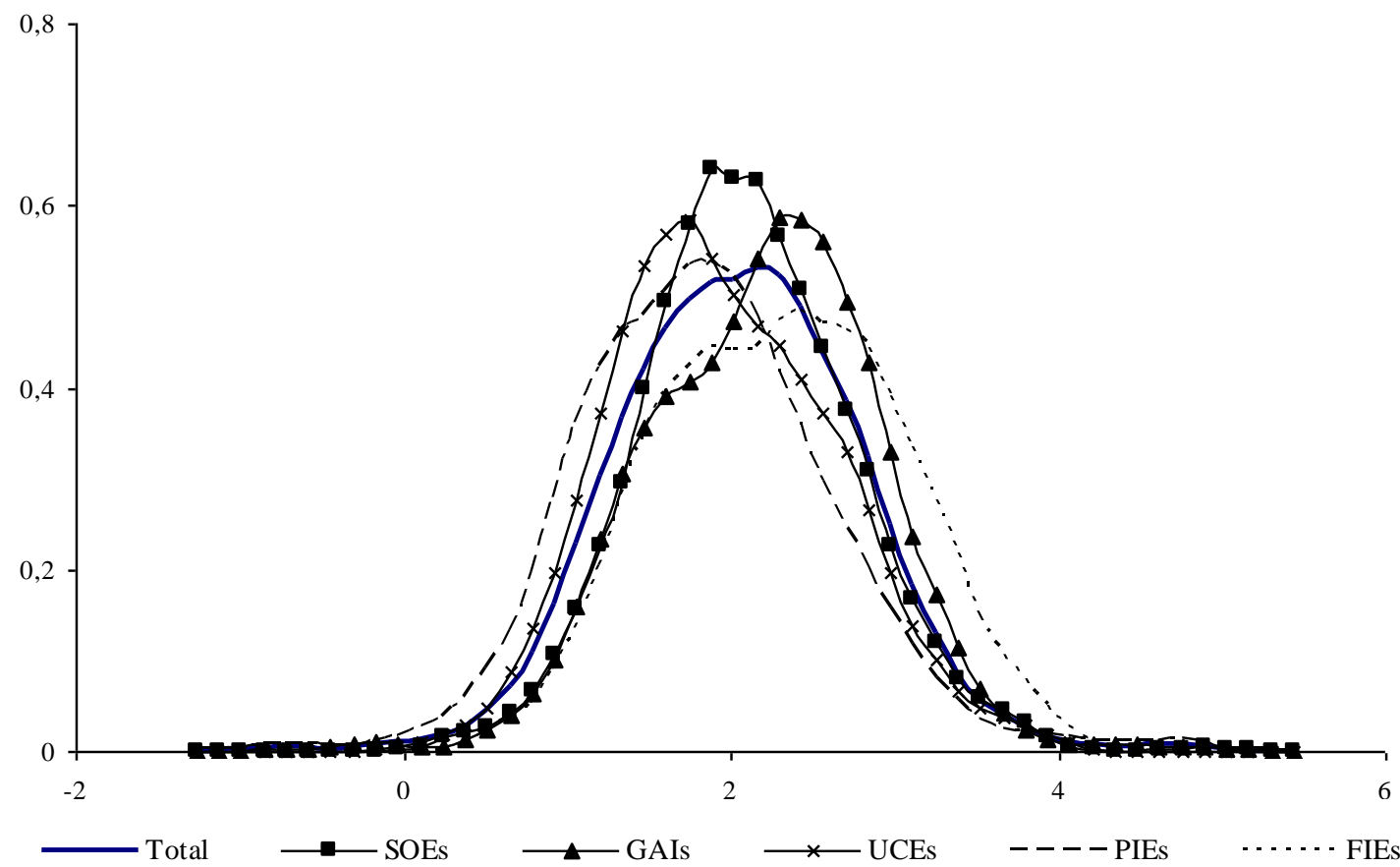

Source: Authors' calculations using the CHIP-2002 and RUMIC-2007 survey data.

Note: See Table 2. Earnings are deflated using the urban provincial-level spatial price deflators calculated by Brandt and Holz (2006) and are updated for the year 2007. Base: nationwide prices in 2002. 
Figure 2 - Juhn-Murphy-Pierce decomposition of log hourly wages by ownership
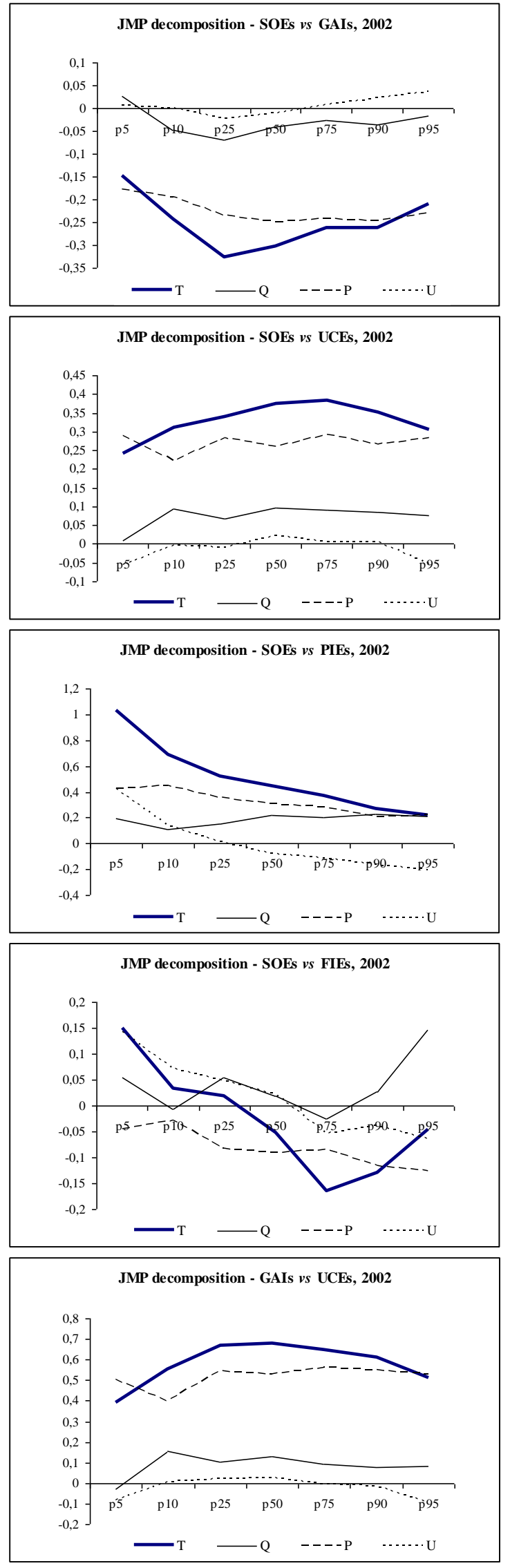
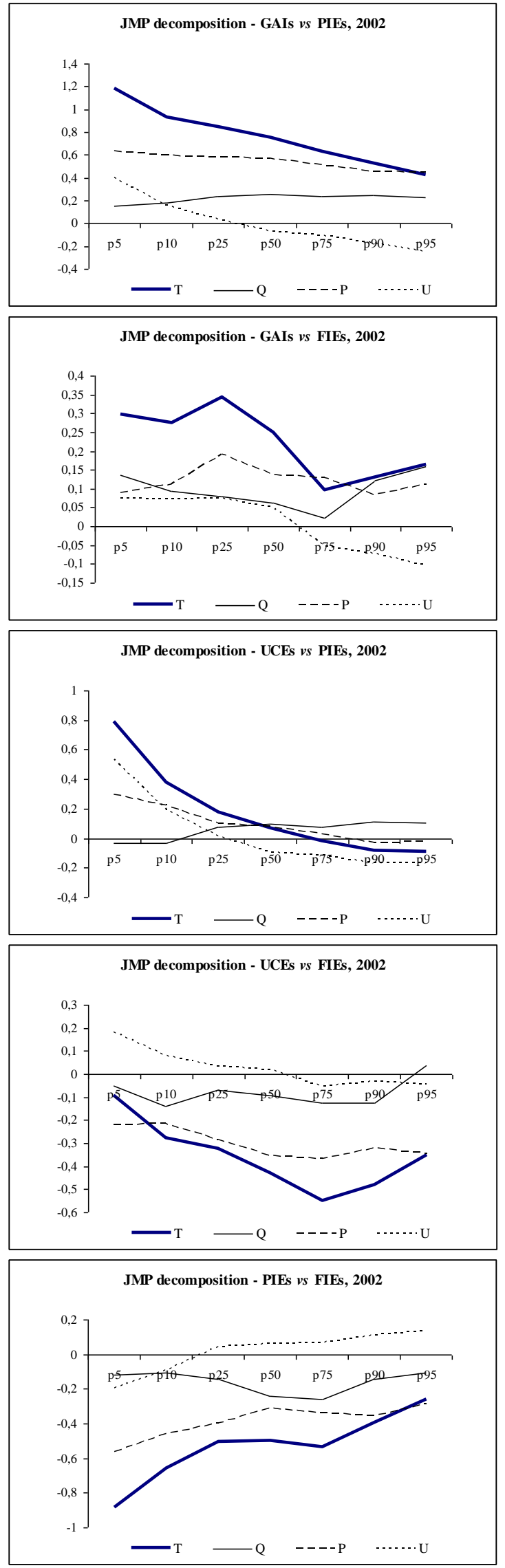

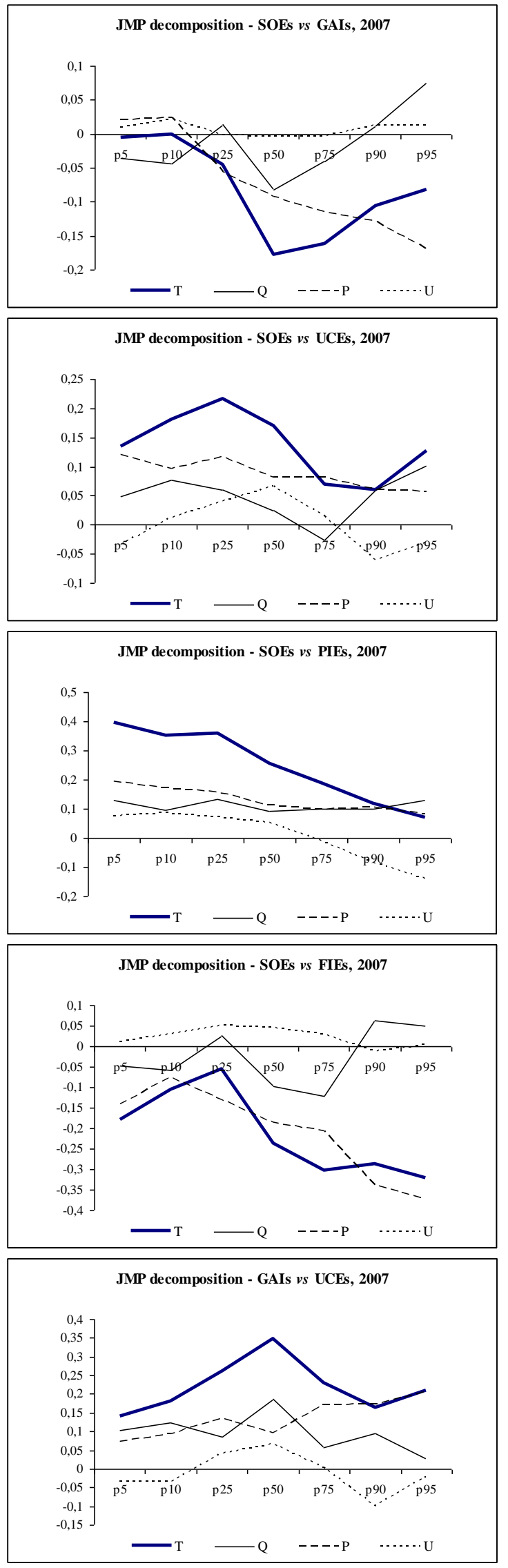
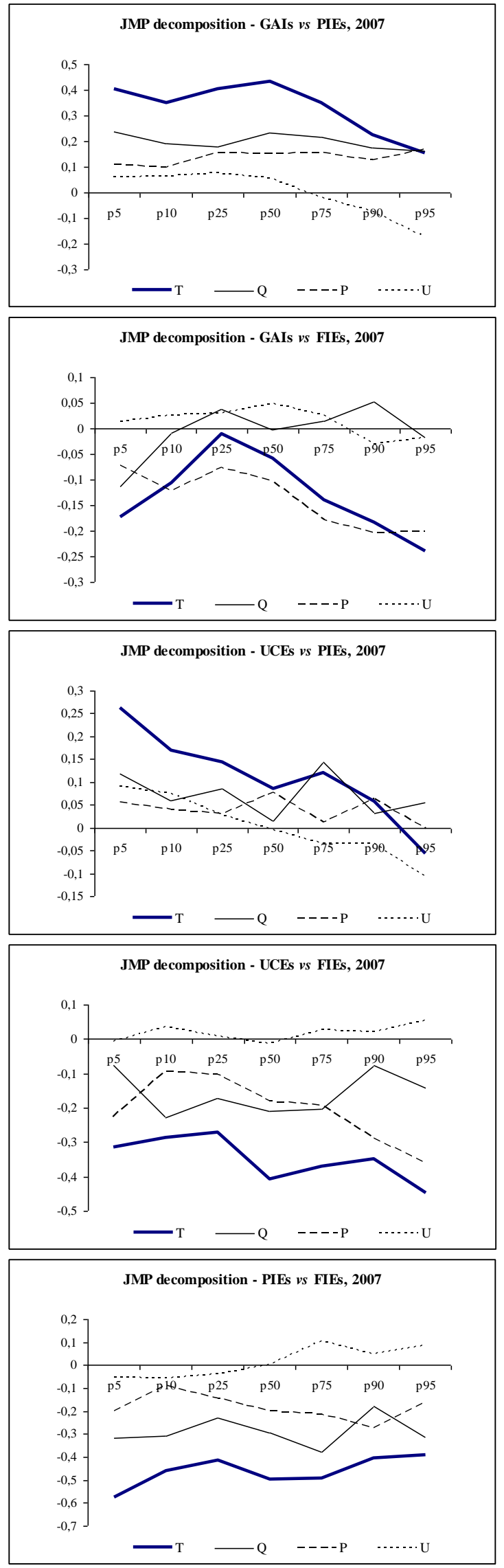
